\title{
GENETIC STRUCTURE AND ASSOCIATION ANALYSIS OF YIELD AND GRAIN LENGTH TRAITS IN RICE GERMPLASM ACCESSIONS
}

\author{
Ritu R. Saxena ${ }^{1}$, Pratibha V. Mohan ${ }^{2}$, Hemant Sahu ${ }^{1}$, Parmeshwar K. Sahu ${ }^{1 *}$, Suman Rawte ${ }^{1}$, \\ Richa Sao, Ravi R. Saxena ${ }^{3}$, S. B. Verulkar ${ }^{2}$
}

${ }^{1}$ Department of Genetics and Plant Breeding, College of Agriculture, Indira Gandhi Agriculture University, Raipur (Chhattisgarh), India
${ }^{2}$ Department of Plant Molecular Biology and Biotechnology, College of Agriculture, Indira Gandhi Agriculture University, Raipur (Chhattisgarh), India
${ }^{3}$ Department of Agricultural Statistics and Social Sciences (L), College of Agriculture, Indira Gandhi Agriculture University, Raipur (Chhattisgarh), India

Received - March 28, 2020; Revision - May 27, 2020; Accepted - June 19, 2020

Available Online - June 25, 2020

DOI: http://dx.doi.org/10.18006/2020.8(3).241.252

KEYWORDS
Association mapping
Germplasm
QTLs
Rice
SSR

\begin{abstract}
Rice is a primary staple food for more than half of the world's population and more that $70 \%$ of Indian population. Chhattisgarh state is one of the major parts of India having richest rice biodiversity with wide genetic diversity. To make advances in rice molecular design breeding, it is important to understand the genetic background and phenotypes of germplasm lines, to know superior alleles of the breeding material. An attempt was made to identify the marker trait association for grain features with SSR markers and to identify the genetic diversity and population structure in rice germplasm lines of Chhattisgarh. In this study, 59 SSR markers were used to analyze differentiation pattern in 48 rice germplasm lines. The genetic structure showed that 48 indica lines were divided into two subgroups based on grain morphology. Sub population-1 and sub-population-2, consisted 23-23 genotypes respectively whereas two genotypes were of admixture type. Results of neighbour-joining tree (NJ tree) and PCoA analysis showed similar results of population structure analysis. GWAS analysis identified total 25 significant marker-trait associations. Of which five for grain length, four for grain length: breadth ratio, twelve for grain yield and four for thousand-grain weights were recorded. RM135 and RM201 were significantly associated with three traits viz., grain length, grain L: B ratio and total grain weight. We do hope that the results obtained through this study will be useful for future breeding programmes.
\end{abstract}

* Corresponding author

E-mail: parmeshwarsahu1210@gmail.com (Parmeshwar K. Sahu)

Peer review under responsibility of Journal of Experimental Biology and Agricultural Sciences.

Production and Hosting by Horizon Publisher India [HPI] (http://www.horizonpublisherindia.in/).

All rights reserved.
All the articles published by Journal of Experimental Biology and Agricultural Sciences are licensed under a Creative Commons Attribution-NonCommercial 4.0 International License Based on a work at www.jebas.org.

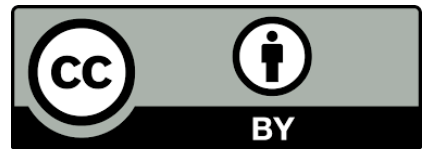




\section{Introduction}

Rice (Oryza sativa L.) is one of the major staple foods belonging to more than half of the world's population. Increasing the productivity of rice is essential to feed the burgeoning population. Moreover, demand of quality rice is increasing as living standard of people has improved (Sahu et al., 2019). Preference for rice with different grain size (long and short) varies region to region. Hence, there is a need to breed high-quality rice with higher yield potential. (Huang et al., 2013; Li et al., 2020).

Since rice grain length is quantitatively inherited (McKenzie \& Rutger, 1983), it is difficult for breeders to efficiently improve grain appearance using conventional selection methods. Thus, it should be particularly helpful for enhancing breeding efficiency to use markers closely linked to genes or major quantitative trait loci (QTLs) for grain length to screen target genotypes directly in early generations (Weng et al., 2008). In rice, numerous studies have been conducted to genetically map QTLs for grain yield traits, and thousands of QTLs have been detected during the past several decades (Li et al., 2020). Grain size and shape are important determinants of grain yield and grain quality, which are usually controlled by QTLs. More than 400 QTLs responsible for grain shape and size were reported by various scientists (Shao et al., 2012; Huang et al., 2013).

Many QTLs for rice grain size traits have been reported in the last decade (Huang et al., 2013). Among them, $q G L 3$ (Zhang et al., 2012), GW8 (Wang et al., 2012), GS5 (Li et al., 2011), GS3 (Mao et al., 2010), GW5 (Weng et al., 2008) and $q S W 5$ (Shomura et al., 2008) have been cloned, and $g w 3.1$ (Li et al., 2004), $q G L 7$ (Bai et al., 2010), GS7 (Shao et al., 2012) and $g w 9.1$ (Xie et al., 2008) have been fine mapped. Thus, understanding the genetic and molecular basis of grain size is extremely important for rice improvement programs. Molecular marker technique has proved valuable in identification of loci involved in quantitative traits related to grain quality characters and has provided insight into its complex relationship with associated factors and their underlying genes are now far more accessible (Weng et al., 2008).

Association mapping has proven significance for identification and mapping of QTLs for various desired in rice germplasm populations. In this study, total 48 germplasm lines of rice with high and low grain length and 59 SSR markers were used to assess the genetic diversity and the same were applied to population structure. Moreover, association analysis was undertaken between SSR markers and four grain parameters. Aim of present study was to distinguish the population structure of selected rice varieties and to identify SSR markers, associated significantly with rice grain yield, grain length, and grain length: breadth and thousand-grain weight.

\section{Materials and Methods}

\subsection{Plant materials}

For current study, total 48 rice germplasm lines including 24 shortgrain length lines ranging from 5.5 to $6.0 \mathrm{~mm}$ and 24 long grain lines ranging from 11.0 to $12.6 \mathrm{~mm}$ were procured from Rice Biodiversity Division of Indira Gandhi Krishi Vishwavidyalaya, Raipur (C.G.), India (Table 1).

Table 1 List of rice landraces used in the study and their origin

\begin{tabular}{|c|c|c|c|}
\hline S. No. & Accession Name & S. No. & Accession Name \\
\hline 1 & Lokti Machhi & 25 & Farsa phool \\
\hline 2 & Atma Sital & 26 & Jay Bajrang \\
\hline 3 & Lokti Machhi & 27 & Gilas \\
\hline 4 & ADT:27 & 28 & Khatia pati \\
\hline 5 & Anjania & 29 & Mani \\
\hline 6 & Kanak Jira & 30 & Khatriya pati \\
\hline 7 & Jhumera & 31 & Girmit \\
\hline 8 & Kakeda (I) & 32 & Lanji \\
\hline 9 & Dubraj II & 33 & Banreg \\
\hline 10 & Bhulau & 34 & Ruchi \\
\hline 11 & Rani kajar & 35 & Safed luchai \\
\hline 12 & Sundar mani & 36 & Kanthi deshi \\
\hline 13 & Bhado kanker & 37 & Piso III \\
\hline 14 & Jhumarwa & 38 & Kakdi \\
\hline 15 & Bishnu & 39 & Gajpati \\
\hline 16 & Basa Bhog & 40 & Gadur sela \\
\hline 17 & Krishna Bhog & 41 & Aadan chilpa \\
\hline 18 & Hira Nakhi & 42 & Unknown \\
\hline 19 & Lokti Maudi & 43 & Saja chhilau \\
\hline 20 & Kariya bodela bija & 44 & Parmal Safri \\
\hline 21 & Ganja Kali & 45 & Safri \\
\hline 22 & Banas KupiII & 46 & Narved \\
\hline 23 & Dhangari Khusha & 47 & Nagbel \\
\hline 24 & Bhaniya & 48 & Mudariya \\
\hline
\end{tabular}




\subsection{Field experiments}

Experimental materials were grown under field condition by following the Randomized Complete Block Design (RCBD) with three replications during the wet season of 2015. The crop was maintained under irrigated condition. Standard agronomical practices were adopted for all the treatments. Five random plants from each of the plot were taken for recording data on agro-morphological and yield characters.

\subsection{Phenotyping of rice germplasm lines for grain yield and grain characteristics}

The average length of randomly selected ten hulled spikelets was measured in terms of millimetres. This is grouped into the very short, short, medium, long and very long grain. The grain length/breadth ratio of randomly selected ten hulled spikelets was calculated by dividing respective length with breadth. A thousand seeds of each of the entry were taken randomly and weighed in gram. The grain yield per plant for total five plants was recorded individually after drying the seeds for 5-8 days after harvesting and averaged value were used for further analysis.

\subsection{Genotyping of rice landraces based on SSR markers}

Total 59 SSR markers distributed on 12 chromosomes were used in this study (https://archive.gramene.org/ markers/) (Table 2). DNA was extracted using the CTAB method (Murray \& Thompson, 1980). The reaction volume for PCR was kept $10 \mu$. The PCR reaction was carried out on a 96-well plate with temperature profile of $94^{\circ} \mathrm{C}$ for $5 \mathrm{~min}$ (denaturation); 35 cycles of $94^{\circ} \mathrm{C}$ for the $50 \mathrm{~s}$ (denaturation), $55^{\circ} \mathrm{C}$ for $50 \mathrm{~s}$ (annealing) and $72^{\circ} \mathrm{C}$ for 1 $\min$ (extension); and $7 \mathrm{~min}$ of final extension at $72^{\circ} \mathrm{C}$. The amplified products were size-separated by using $5 \%$ polyacrylamide gel electrophoresis and detected by Ethidium bromide stain $(10 \mu \mathrm{l} / 100 \mathrm{ml})$ and visualized in BIO RAD Gel Doc XR+ (Sahu et al., 2017).

\subsection{Statistical Analysis}

The morphological data were managed using Excel 2007 (MS Excel, 2007), and the descriptive statistics and variance analysis were produced using SPSS 16.0 (IBM SPSS). Broad sense heritability was calculated by using OPSTAT. Informativeness of molecular markers and their diversity parameters viz., average number of alleles per locus, gene diversity (He), and the Polymorphic information content (PIC) values were calculated using Power Marker v3.25 (Liu \& Muse, 2005).
Table 2 List of 59 microsatellite markers with their chromosome locations, number of alleles, allele size and PIC value found among 48 rice accessions.

\begin{tabular}{|c|c|c|c|c|c|}
\hline S. No. & Marker & Amplicon Size & $\begin{array}{l}\text { No. of } \\
\text { Alleles }\end{array}$ & $\begin{array}{c}\text { Chromosome } \\
\text { No.\# }\end{array}$ & PIC Value \\
\hline 1 & RM 1 & $67-119$ & 11 & 1 & 0.87 \\
\hline 2 & RM 5 & $94-138$ & 6 & 1 & 0.74 \\
\hline 3 & RM11 & $118-151$ & 3 & 7 & 0.49 \\
\hline 4 & RM 19 & $192-250$ & 10 & 12 & 0.85 \\
\hline 5 & RM 25 & $121-159$ & 6 & 8 & 0.79 \\
\hline 6 & RM 30 & $100-140$ & 1 & 6 & 0.00 \\
\hline 7 & RM 104 & $222-238$ & 1 & 1 & 0.00 \\
\hline 8 & RM 105 & $100-141$ & 4 & 9 & 0.59 \\
\hline 9 & RM 125 & $105-147$ & 3 & 7 & 0.12 \\
\hline 10 & RM 130 & $73-81$ & 2 & 3 & 0.22 \\
\hline 11 & RM 132 & $70-85$ & 2 & 3 & 0.50 \\
\hline 12 & RM 134 & $92-94$ & 2 & 7 & 0.04 \\
\hline 13 & RM 135 & $100-150$ & 7 & 3 & 0.81 \\
\hline 14 & RM 148 & $190-210$ & 4 & 3 & 0.65 \\
\hline 15 & RM 152 & $133-157$ & 3 & 8 & 0.64 \\
\hline 16 & RM 154 & $148-230$ & 3 & 2 & 0.55 \\
\hline 17 & RM 161 & $154-187$ & 3 & 5 & 0.28 \\
\hline 18 & RM 168 & $96-116$ & 2 & 3 & 0.64 \\
\hline 19 & RM 171 & $307-347$ & 5 & 10 & 0.77 \\
\hline 20 & RM 172 & $159-165$ & 2 & 7 & 0.49 \\
\hline 21 & RM 175 & $80-95$ & 2 & 3 & 0.15 \\
\hline 22 & RM 186 & $115-132$ & 3 & 3 & 0.51 \\
\hline 23 & RM 201 & $155-350$ & 2 & 9 & 0.48 \\
\hline 24 & RM 215 & $126-161$ & 3 & 9 & 0.38 \\
\hline 25 & RM 218 & $100-120$ & 4 & 3 & 0.64 \\
\hline 26 & RM 231 & $157-182$ & 3 & 3 & 0.55 \\
\hline 27 & RM 234 & $133-163$ & 3 & 7 & 0.26 \\
\hline 28 & RM 242 & $200-290$ & 4 & 9 & 0.32 \\
\hline 29 & RM 248 & $75-100$ & 4 & 7 & 0.53 \\
\hline 30 & RM 287 & $82-118$ & 3 & 11 & 0.46 \\
\hline 31 & RM 316 & $194-216$ & 3 & 9 & 0.55 \\
\hline 32 & RM 338 & $178-184$ & 2 & 3 & 0.35 \\
\hline 33 & RM 408 & $112-128$ & 2 & 8 & 0.50 \\
\hline 34 & RM 422 & $385-450$ & 5 & 3 & 0.76 \\
\hline 35 & RM 431 & $233-261$ & 2 & 1 & 0.25 \\
\hline
\end{tabular}




\begin{tabular}{|c|c|c|c|c|c|}
\hline S. No. & Marker & Amplicon Size & $\begin{array}{l}\text { No. of } \\
\text { Alleles }\end{array}$ & $\begin{array}{c}\text { Chromosome } \\
\text { No.\# }\end{array}$ & PIC Value \\
\hline 36 & RM 432 & $150-187$ & 5 & 7 & 0.76 \\
\hline 37 & RM 433 & $216-248$ & 2 & 8 & 0.49 \\
\hline 38 & RM 436 & $83-134$ & 4 & 7 & 0.66 \\
\hline 39 & RM 447 & $95-146$ & 4 & 8 & 0.72 \\
\hline 40 & RM 455 & $127-144$ & 6 & 7 & 0.79 \\
\hline 31 & RM 316 & $194-216$ & 3 & 9 & 0.55 \\
\hline 32 & RM 338 & $178-184$ & 2 & 3 & 0.35 \\
\hline 33 & RM 408 & $112-128$ & 2 & 8 & 0.50 \\
\hline 34 & RM 422 & $385-450$ & 5 & 3 & 0.76 \\
\hline 35 & RM 431 & $233-261$ & 2 & 1 & 0.25 \\
\hline 36 & RM 432 & $150-187$ & 5 & 7 & 0.76 \\
\hline 37 & RM 433 & $216-248$ & 2 & 8 & 0.49 \\
\hline 38 & RM 436 & $83-134$ & 4 & 7 & 0.66 \\
\hline 39 & RM 447 & $95-146$ & 4 & 8 & 0.72 \\
\hline 40 & RM 455 & $127-144$ & 6 & 7 & 0.79 \\
\hline 41 & RM 468 & $260-350$ & 4 & 3 & 0.72 \\
\hline 42 & RM 481 & $95-200$ & 6 & 7 & 0.79 \\
\hline 43 & RM 489 & $248-314$ & 3 & 3 & 0.29 \\
\hline 44 & RM 501 & $130-179$ & 3 & 7 & 0.53 \\
\hline 45 & RM 517 & $260-287$ & 3 & 3 & 0.57 \\
\hline 46 & RM 520 & $200-290$ & 4 & 3 & 0.69 \\
\hline 47 & RM 523 & $130-150$ & 3 & 3 & 0.55 \\
\hline 48 & RM 527 & $200-233$ & 2 & 6 & 0.33 \\
\hline 49 & RM 545 & $150-230$ & 3 & 3 & 0.53 \\
\hline 50 & RM 546 & $115-150$ & 1 & 3 & 0.00 \\
\hline 51 & RM 560 & $237-368$ & 3 & 7 & 0.52 \\
\hline 52 & RM 569 & $170-185$ & 2 & 3 & 0.15 \\
\hline 53 & RM 22565 & $200-280$ & 5 & 8 & 0.55 \\
\hline 54 & RM 22710 & $150-180$ & 1 & 8 & 0.44 \\
\hline 55 & RM 3825 & $147-200$ & 3 & 1 & 0.70 \\
\hline 56 & OSR-13 & $85-122$ & 2 & 8 & 0.00 \\
\hline 57 & Xa- $5 \mathrm{~S}$ & 300 & 1 & 5 & 0.00 \\
\hline 58 & Хa-13 Pro & $290-610$ & 1 & 8 & 0.00 \\
\hline 59 & Ха-21 & $800-1200$ & 3 & 11 & 0.23 \\
\hline
\end{tabular}

The population structure analysis was performed in STRUCTURE v2.3.4 (Earl \& Von Holdt, 2012) using a burn-in period of 100,000 and MCMC replicates of 100,000 . The number of groups $(\mathrm{K})$ was set from 1 to 10 , with five iterations. Probable structure number $(\mathrm{K})$ was estimated by Evanno's method at Structure Harvester software (Evanno et al., 2005). The rice lines with membership probability of 0.80 or above were considered in a specific group whereas genotypes with membership probability of $\mathrm{Q}<0.80$ were considered as Admixture type (AD) (Zhang et al., 2011). TASSEL v4.3 was also used to calculate Jaccard's similarity-based Neighbour-Joining tree (Liu \& Muse, 2005). XLSTAT was used for PCoA analysis based on the molecular markers.

The association mapping analysis was performed by TASSEL v2.3 (Bradbury et al., 2007) using the mixed linear model (MLM). The model MLM_Q+K, using kinship matrix and Q-matrix as the concomitant variable, was used to identify the marker-trait association. Marker trait association at $\mathrm{P}<0.01$ were considered significant.

\section{Results}

\subsection{Variation parameters of yield and grain related traits}

Descriptive statistics of the four yield and grain related traits are given in Table 3. Results of the study showed that grain length ranges from $5.11 \mathrm{~mm}$ to $11.80 \mathrm{~mm}$ with an average of $8.21 \mathrm{~mm}$ and standard deviation of $2.54 \mathrm{~mm}$ whereas grain L: B ratio ranges from 1.91 to 5.84 with mean 3.32 and standard deviation 1.11. Based on the grain length, rice landraces were categorized into two broad categories i.e., short-grain rice and long grain rice (Table 4) whereas mean value of grain length and grain L: B ratio is given in Table 5. Grain yield per plant ranges from $15(\mathrm{~g})$ to $35.5(\mathrm{~g})$ with an average of $25.75(\mathrm{~g})$ and standard deviation $7.65(\mathrm{~g})$ whereas thousand-grain weight ranges from $10.35(\mathrm{~g})$ to $33.65(\mathrm{~g})$ with mean $23.3(\mathrm{~g})$ and standard deviation $7.65(\mathrm{~g})$. Descriptive statistics revealed sufficient variation for all four traits within the studied genotypes. Coefficient of variations ranges from 30.85 to $38.58 \%$. Analysis of variance revealed that treatments were highly significant for all four traits which showed the presence of sufficient variation for these traits (Table 6). The broadsense heritability of the traits was $>90 \%$ except for grain yield, which was only $78.61 \%$, suggesting that there is less environmental impact on these traits.

Journal of Experimental Biology and Agricultural Sciences http://www.jebas.org 
Table 3 Descriptive statistics for GL, GL: B, GY and TSW in 48 rice germplasm accessions

\begin{tabular}{|ccccccc|c|}
\hline Trait & Mini mum & Maxi mum & Mean & Std. Error Std. Deviation & $\begin{array}{c}\text { CV (\%) } \\
\text { Heritability } \\
\left(\mathrm{h}^{2}{ }_{\mathrm{bs}}\right)(\%)\end{array}$ \\
\hline Grain length (GL), & 5.15 & 11.80 & 8.21 & 0.37 & 2.53 & 30.85 & 99.57 \\
\hline Grain length:breadth ratio (GL: B) & 1.91 & 5.84 & 3.32 & 0.16 & 1.11 & 33.41 & 97.71 \\
\hline Grain yield (GY) & 15.00 & 35.50 & 25.75 & 1.12 & 7.65 & 36.89 & 78.61 \\
\hline Thousand seed weight (TSW) & 10.35 & 33.65 & 22.03 & 1.23 & 8.50 & 38.58 & 99.93 \\
\hline
\end{tabular}

Table 4 Germplasm categorized into very short, short, medium and long grain length

\begin{tabular}{|cl|}
\hline Category & \multicolumn{1}{c|}{$\begin{array}{c}\text { Name of accession } \\
\text { Short grain rice germplasm }\end{array}$} \\
\hline Very short & $\begin{array}{l}\text { Lokti Machhi; Atma Sital; Lokti Machhi; Anjania; Jhumera; Kakeda (I); Dubraj II; Bhulau; Rani kajar; Bhado kanker; } \\
\text { Jhumarwa; Bishnu; Basa Bhog; Krishna Bhog; Hira Nakhi; Lokti Maudi; Gganja Kali; Dhangari Khusha; }\end{array}$ \\
\hline Short & ADT:27; Kanak Jira; Sundar mani; Kariya bodela bija; Banas KupiII; Bhaniya \\
\hline Medium & Lilas; Khatia pati; Mani; Girmit; Lanji; Safed luchai; Gajpati; Saja chhilau; Safri; Narved \\
\hline Long & $\begin{array}{l}\text { Farsa phool; Jay Bajrang; Khatriya pati; Banreg; Ruchi; Kanthi deshi; Piso III; Kakdi; Gadur sela; Aadan chilpa; } \\
\text { Unknown; Parmal Safri; Nagbel; Mudariya }\end{array}$ \\
\hline
\end{tabular}

Table 5 Grain length and grain L:B ratio of various germplasm lines

\begin{tabular}{|c|c|c|c|}
\hline Name of Germplasm & Grain length (mm) & Name of Germplasm & $\begin{array}{l}\text { Grain shape } \\
\text { (L: B ratio) }\end{array}$ \\
\hline Jhumarwa & 5.15 & Basa Bhog & 1.91 \\
\hline Rani kajar & 5.20 & Dubraj II & 1.97 \\
\hline Basa Bhog & 5.25 & Bhulau & 2.02 \\
\hline Dhangari Khusha & 5.25 & Bhado kanker & 2.08 \\
\hline Krishna Bhog & 5.25 & Krishna Bhog & 2.14 \\
\hline Lokti Machhi & 5.25 & Jhumarwa & 2.15 \\
\hline Bhado kanker & 5.50 & Ganja Kali & 2.15 \\
\hline Bhulau & 5.55 & Rani kajar & 2.17 \\
\hline Lokti Machhi & 5.65 & Hira Nakhi & 2.19 \\
\hline Atma Sital & 5.70 & Lokti Maudi & 2.25 \\
\hline Ganja Kali & 5.70 & ADT:27 & 2.27 \\
\hline Bishnu & 5.75 & Kanak Jira & 2.28 \\
\hline Jhumera & 5.75 & Lokti Machhi & 2.33 \\
\hline Dubraj II & 5.80 & Jhumera & 2.35 \\
\hline Kakeda (I) & 5.80 & Kakeda (I) & 2.37 \\
\hline Anjania & 5.85 & Anjania & 2.44 \\
\hline Lokti Maudi & 5.85 & Sundar mani & 2.45 \\
\hline Hira Nakhi & 5.90 & Lokti Machhi & 2.46 \\
\hline
\end{tabular}

Journal of Experimental Biology and Agricultural Sciences http://www.jebas.org 


\begin{tabular}{|c|c|c|c|}
\hline Name of Germplasm & Grain length (mm) & Name of Germplasm & $\begin{array}{l}\text { Grain shape } \\
\text { (L: B ratio) }\end{array}$ \\
\hline Sundar mani & 6.00 & Bishnu & 2.56 \\
\hline Kanak Jira & 6.05 & Atma Sital & 2.65 \\
\hline Banas KupiII & 6.10 & Kariya bodela bija & 2.73 \\
\hline ADT:27 & 6.25 & Dhangari Khusha & 2.76 \\
\hline Bhaniya & 6.50 & Banas KupiII & 2.77 \\
\hline Kariya bodela bija & 6.70 & Saja chhilau & 2.93 \\
\hline Khatia pati & 9.70 & Unknown & 3.31 \\
\hline Mani & 9.85 & Farsa phool & 3.44 \\
\hline Lanji & 10.05 & Bhaniya & 3.51 \\
\hline Narved & 10.10 & Aadan chilpa & 3.59 \\
\hline Gilas & 10.35 & Nagbel & 3.63 \\
\hline Saja chhilau & 10.40 & Lanji & 3.72 \\
\hline Girmit & 10.45 & Mudariya & 3.81 \\
\hline Safed luchai & 10.45 & Girmit & 3.87 \\
\hline Safri & 10.45 & Gadur sela & 3.89 \\
\hline Gadur sela & 10.50 & Gajpati & 3.98 \\
\hline Gajpati & 10.55 & Ruchi & 4.04 \\
\hline Kakdi & 10.70 & Khatia pati & 4.04 \\
\hline Ruchi & 10.70 & Gilas & 4.06 \\
\hline Unknown & 10.75 & Safri & 4.35 \\
\hline Parmal Safri & 10.80 & Kakdi & 4.46 \\
\hline Piso III & 10.80 & Narved & 4.49 \\
\hline Farsa phool & 10.85 & Mani & 4.58 \\
\hline Kanthi deshi & 10.90 & Banreg & 4.72 \\
\hline Aadan chilpa & 10.95 & Piso III & 4.91 \\
\hline Mudariya & 11.05 & Jay Bajrang & 4.92 \\
\hline Banreg & 11.10 & Khatriya pati & 4.96 \\
\hline Khatriya pati & 11.40 & Safed luchai & 5.23 \\
\hline Nagbel & 11.45 & Kanthi deshi & 5.59 \\
\hline Jay Bajrang & 11.80 & Parmal Safri & 5.84 \\
\hline
\end{tabular}

Table 6 Analysis of variance (ANOVA) based on Randomized Block Design (RBD) for grain length, grain length: breadth ratio, thousand grain weight and grain yield per plant

\begin{tabular}{cccccc|}
\hline SV & DF & & \multicolumn{3}{c|}{ Mean sum of squares } \\
& & GL & GL: B & TGW & 0.07 \\
\hline Replication & 1 & 0.003 & $37^{* *}$ & $144.58^{* *}$ & $8,927.39^{* *}$ \\
\hline Treatment & 47 & $12.82^{* *}$ & $58.65^{* *}$ & 0.05 & 6130.45 \\
\hline Error & 47 & 0.028 & 0.68 & \\
\hline
\end{tabular}

Journal of Experimental Biology and Agricultural Sciences http://www.jebas.org 
Table 7 Genetic diversity parameters of molecular markers

\section{Germplasm}

Major Allele Frequency

Allele No.

Gene Diversity (He)

Entire collection

0.62

3.39

0.47

0.42

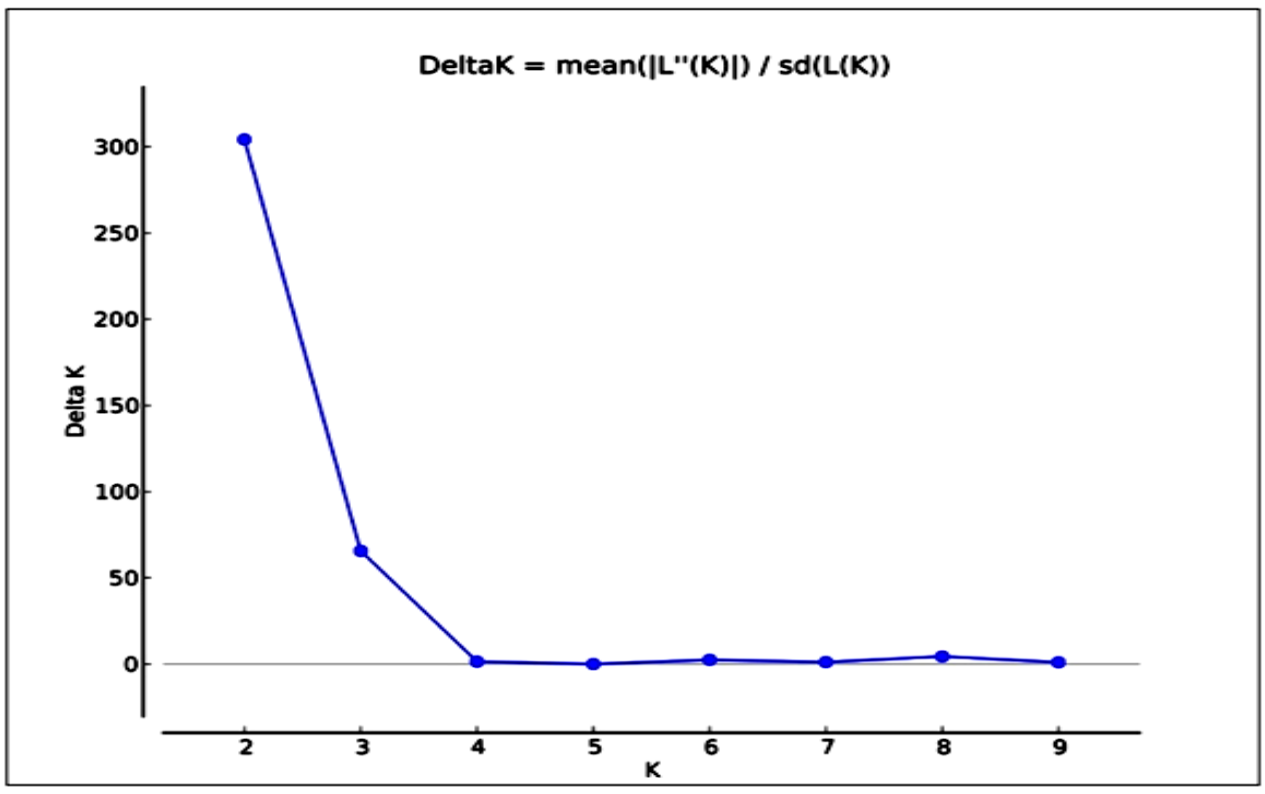

Optimum number of $\mathrm{K}=\mathbf{2}$

Figure 1 Estimation of $\mathrm{K}$ and population structure. Changes in $\Delta \mathrm{K}$ value with the number of subpopulations.

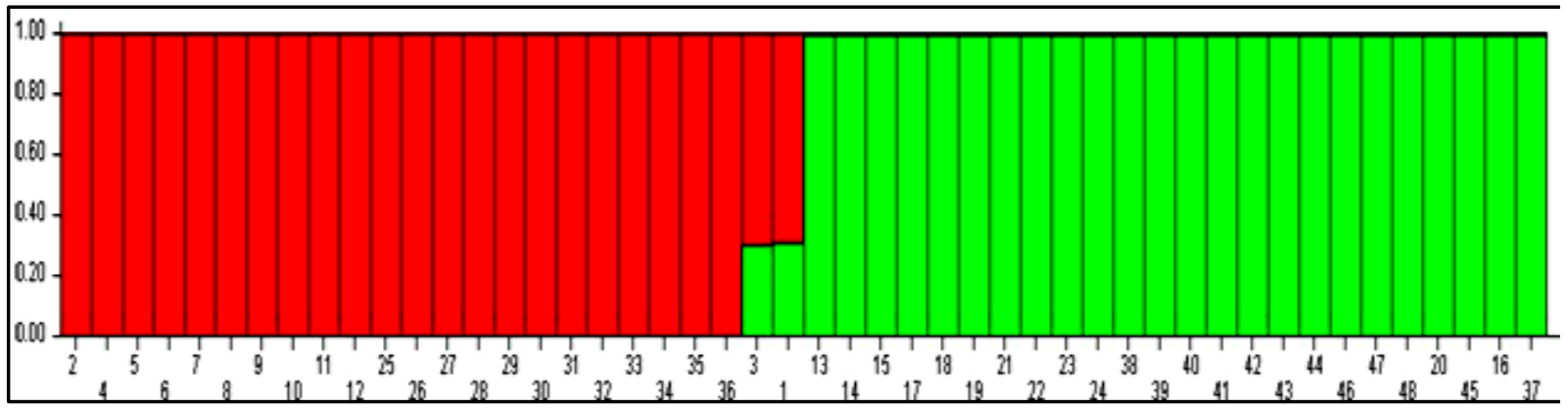

Figure 2 Bar plot showing the population structure of 48 rice landraces based on SSR markers at $\mathrm{K}=2$.

\subsection{Informativeness of molecular markers and their diversity parameters:}

By using 59 SSR markers, 202 alleles were detected in the 48 rice lines in total. The allele number ranged from 1 to 11 per locus, with an average of 3.39. The average major allele frequency was 0.62 whereas the gene diversity $(\mathrm{He})$ was in the range of 0.00 to 0.88 with an average of 0.47 . The average PIC was 0.42 (Table 7). The polymorphic markers appear to be adequate in delineating accessions according to their lineage.

\subsection{Population Structure analysis}

Population structure of the 48 rice germplasm lines based on 59 molecular markers was analyzed by Bayesian model based approach. By comparing $\operatorname{LnP}(\mathrm{D})$ and Evanno's $\Delta \mathrm{K}$ values by increasing $\mathrm{K}$ from 1 to 10 . It was reported that $\operatorname{LnP}(\mathrm{D})$ values increased with $\mathrm{K}$, with the highest $\log$ likelihood score at $\mathrm{K}=2$, while $\Delta K$ value was also highest at $K=2$ (Figure 1). This indicated that 48 rice germplasm had a genetic structure of two sub-populations as shown in bar plot (Figure 2). Further, based on 
the membership fractions, genotypes under different populations were categorized as pure and admixtures. The genotypes with the probability more than $\geq 0.80$ score was considered as pure and less than 0.80 score as an admixture. With population inferred ancestry, 23 lines were assigned to subgroup POP1 whereas 23 lines were assigned to subgroup POP2 and two lines were assigned to admixture (AD) (Figure 2). It was observed that the genotypes of subgroup POP1 have long grain type whereas the genotypes of subgroup POP2 have short grain type.

A neighbour-joining tree was constructed based on the Jaccard's similarity coefficient and UPGMA algorithm (Figure 3). The 48 rice lines were grouped in two clusters viz., cluster I and II which corresponded to POP 1 and POP 2, respectively. A scatter plot was generated based on principal coordinate analysis (PCoA) of the binary data matrix developed from the 48 rice genotypes. It demonstrated a clear pattern of two major sub-group (SG-1 and SG-2) differentiations as shown in Figure 4 based on PC1 and PC2 variability. PCoA grouped the 48 germplasm lines into two major groups (Figure 4). First two coordinates viz., PCoA 1 and PCoA 2 explains $75.07 \%$ and $21.86 \%$ variance respectively of the total variation. The result of neighbour joining tree and principal coordinate analysis was similar to result of population structure analysis which indicated that total genotypes structured into two main subgroups.

\subsection{Identification of marker-trait association (MTAs) through} association mapping:

Association analysis between SSR markers and four agronomic traits was carried out using the MLM model over the 48 rice germplasm lines. Marker trait association by mixed linear model (MLM) were analyzed by using molecular marker data matrix, phenotypic data, population inferred ancestry (Q-matrix) and kinship (K) matrix. Total 25 significant marker trait associations (MTAs) were recorded for four traits (Table 8) at the FDR correction level in the entire population explaining $1.02-5.27 \%$ of the phenotypic variance. Total five markers were significantly associated with grain length; four markers were associated with grain L: B ratio, 12 markers were associated with grain yield per plant and four markers were significantly associated with thousand-grain weight.

Two markers viz., RM135 and RM 201 were significantly associated with three traits namely grain length, grain length: breadth ratio and thousand-grain weight. The range of phenotypic variation explained by RM135 is $65.72 \%$ (grain length: breadth ratio) to $80.19 \%$ (grain length) whereas RM201 showed $55.59 \%$ (thousand grain weight) to $68.20 \%$ (grain length). Moreover, RM 168 was significantly associated with two traits viz., grain length and grain length breadth ratio whereas RM218 was significantly

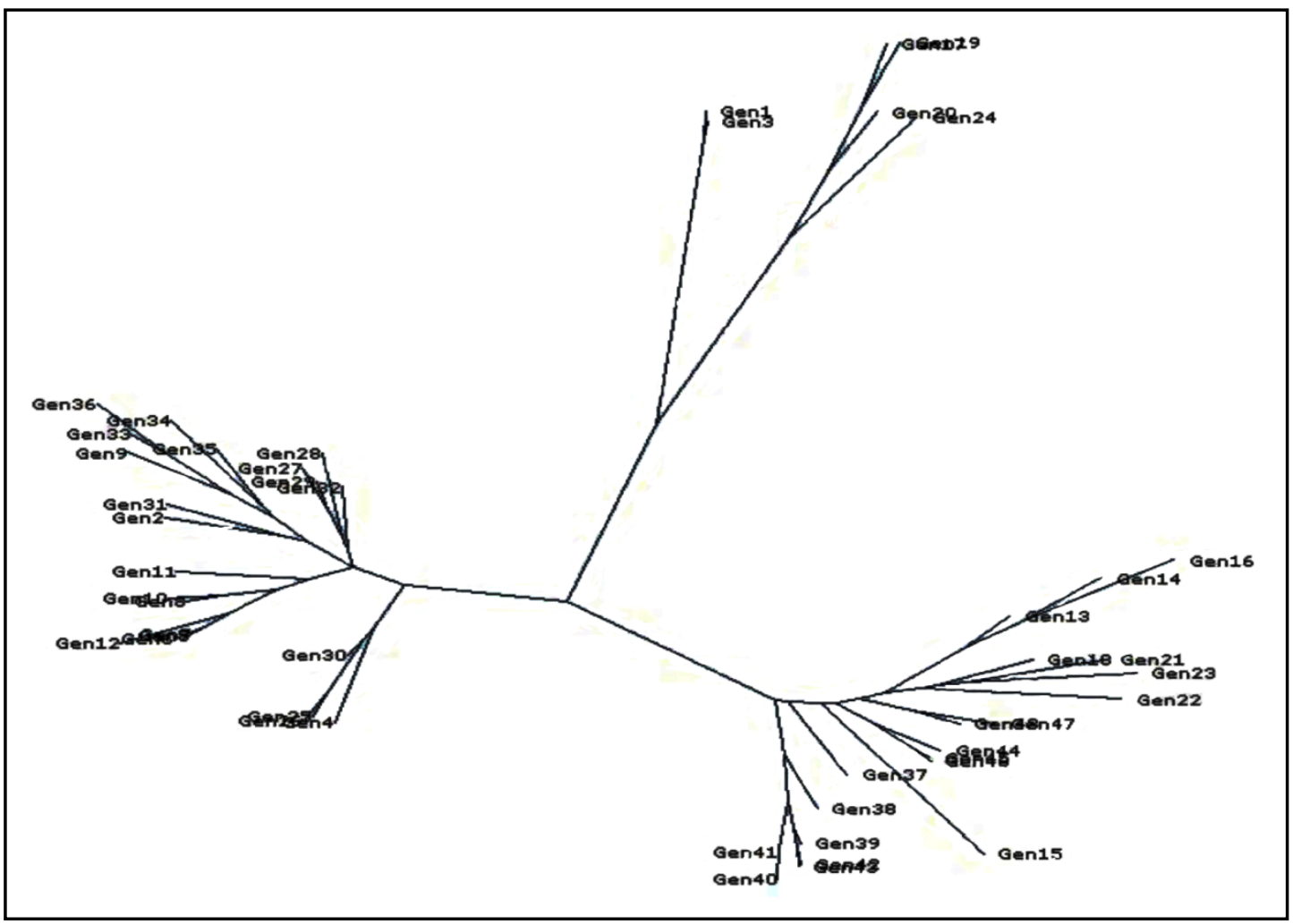

Figure 3 Neighbour-joining tree for the 48 lines based on UPGMA algorithm and Jaccard's similarity coefficient

Journal of Experimental Biology and Agricultural Sciences

http://www.jebas.org 


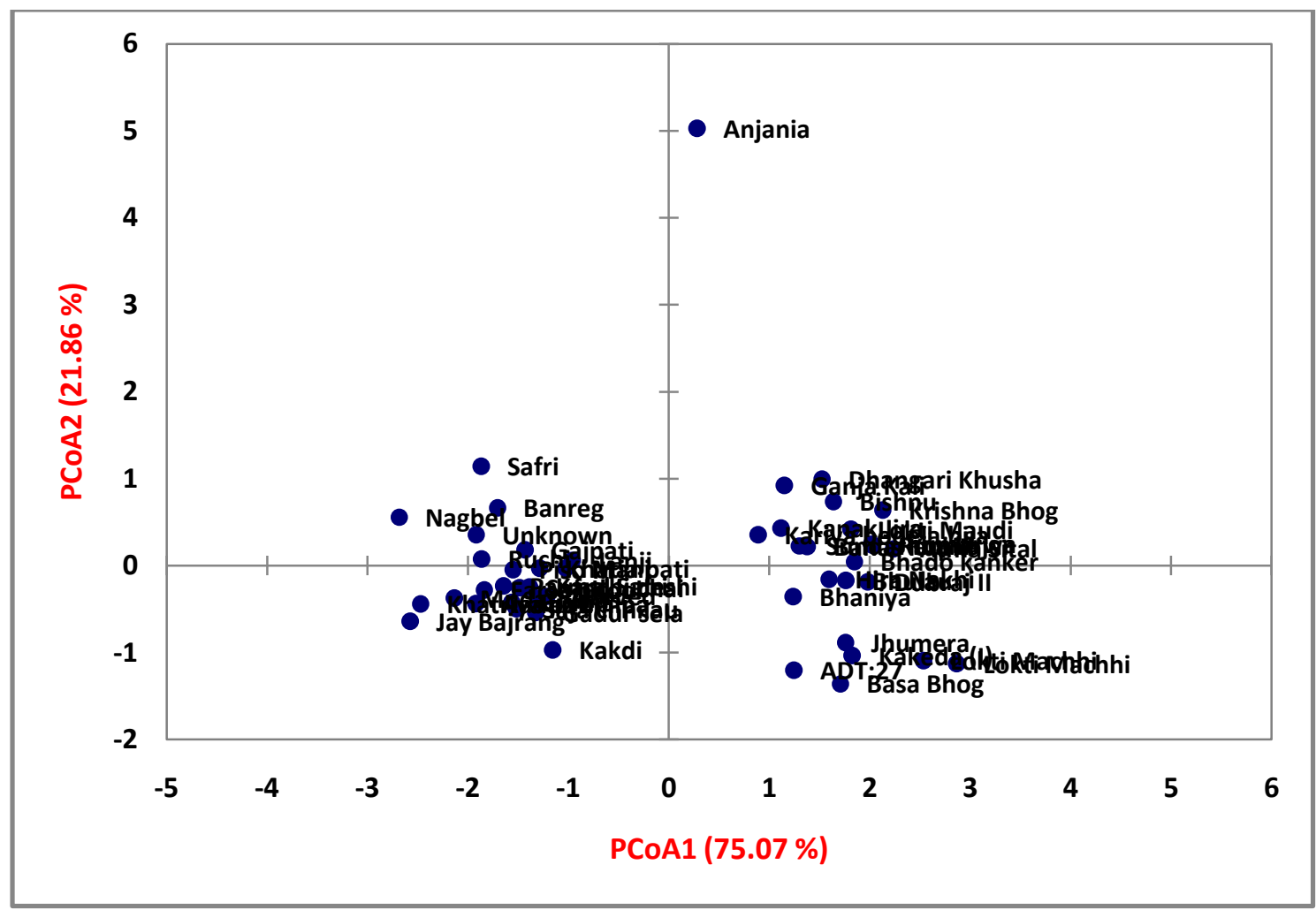

Figure 4 PCoA Scatter diagram of rice germplasm lines based on SSR markers

associated with grain yield per plant and thousand-grain weight. Lowest phenotypic variation (6.8\%) explained by Xa21 marker which was found to be associated with Grain L: B ratio whereas highest phenotypic variation $(80.19 \%)$ was explained by marker RM 135 which was significantly associated with grain length.

\section{Discussion and conclusion}

Analysis of variance revealed significant differences among the genotypes for all four traits which showed the availability of ample variations among the genotypes for studied traits therefore, chances of improvement are more in the base population. Coefficient of variation for the traits was recorded very high due to the presence of diverse germplasm lines in the study. High broadsense heritability was recorded for all the traits which showed the negligible influence of environmental components on transmission and expression these traits. Vanishree et al. (2013) and Devi et al. (2016) also reported wide range of variability for the yield and grain related traits among the rice genotypes which supports the findings of present study.

Molecular markers are promising and effective tools for measuring genetic diversity in germplasm collection and elucidating their evolutionary relationships. Using molecular marker technology, it is now feasible to analyze the quantitative traits and identify the chromosomal regions associating with such characters known as quantitative trait loci (QTLs). Identifying such regions will help to increase the selection efficiency in the breeding program. The polymorphic markers appear to be adequate in delineating accessions according to their lineage. SSR markers used in the study were showing average PIC value 0.42 and gene diversity 0.47 which indicated their effectiveness in polymorphism testing and diversity analysis. These markers can be effectively used in molecular breeding programs and QTL mapping studies since they exhibited very high level of polymorphism over other loci. These results are supported by the outcomes of Li et al. (2011); Huang et al. (2011); Surapaneni et al. (2016) and Li et al. (2020).

The ability to provide genetic distance measures between the genotypes that reflect pedigree relatedness ensures a more stringent evaluation of the adequacy of a marker profile data. Population of rice having high genetic variation may be precious genetic materials for augmenting the genetic base of any breeding program. Genetic diversity and variation available in the population may be quantified through molecular markers, which can be exploited in rice breeding programs. Based on grain shape used rice germplasm lines were divided in two subgroups. Most of the genotypes having long grains were come into subgroup-1 
Table 8 Significant marker-trait associations based on MLM model

\begin{tabular}{|c|c|c|c|c|c|}
\hline S. No. & Trait & Locus & Chr. No. & p_Marker & Rsq_Marker \\
\hline 1 & Grain Length & RM11 & 3 & 0.0402 & 0.3418 \\
\hline 2 & Grain Length & RM 105 & 9 & 0.0496 & 0.4231 \\
\hline 3 & Grain Length & RM 135 & 3 & $2.86 \mathrm{E}-07$ & 0.8019 \\
\hline 4 & Grain Length & RM 168 & 3 & 0.0282 & 0.4582 \\
\hline 5 & Grain Length & RM 201 & 9 & $1.32 \mathrm{E}-04$ & 0.682 \\
\hline 6 & Grain L:B ratio & RM 135 & 3 & $5.27 \mathrm{E}-04$ & 0.6572 \\
\hline 7 & Grain L:B ratio & RM 168 & 3 & 0.0116 & 0.4481 \\
\hline 8 & Grain L:B ratio & RM 201 & 9 & 7.34E-05 & 0.6056 \\
\hline 9 & Grain L:B ratio & Хa-21 & 3 & 0.0084 & 0.0686 \\
\hline 10 & Grain Yield per plant & RM 125 & 7 & 0.0066 & 0.2037 \\
\hline 11 & Grain Yield per plant & RM 132 & 3 & 0.0121 & 0.1317 \\
\hline 12 & Grain Yield per plant & RM 148 & 3 & 0.0339 & 0.1808 \\
\hline 13 & Grain Yield per plant & RM 218 & 3 & 0.0291 & 0.187 \\
\hline 14 & Grain Yield per plant & RM 234 & 7 & 0.043 & 0.1331 \\
\hline 15 & Grain Yield per plant & RM 338 & 3 & 0.048 & 0.0859 \\
\hline 16 & Grain Yield per plant & RM 431 & 1 & 0.0154 & 0.1235 \\
\hline 17 & Grain Yield per plant & RM 481 & 7 & 0.0354 & 0.2452 \\
\hline 18 & Grain Yield per plant & RM 517 & 3 & 0.0437 & 0.1325 \\
\hline 19 & Grain Yield per plant & RM 523 & 3 & 0.0127 & 0.1799 \\
\hline 20 & Grain Yield per plant & RM 527 & 6 & 0.0331 & 0.0969 \\
\hline 21 & Grain Yield per plant & RM 560 & 7 & 0.0443 & 0.1319 \\
\hline 22 & Thousand grain weight & RM 1 & 1 & 0.0407 & 0.7042 \\
\hline 23 & Thousand grain weight & RM 135 & 3 & $9.93 \mathrm{E}-06$ & 0.6786 \\
\hline 24 & Thousand grain weight & RM 201 & 9 & $4.38 \mathrm{E}-04$ & 0.5559 \\
\hline 25 & Thousand grain weight & RM 218 & 3 & 0.0239 & 0.2184 \\
\hline
\end{tabular}

whereas short grain genotypes were present in subgroup-2. Courtois et al. (2012) has also detected two subgroups in their study population and assigned rice varieties into two groups with few admixture lines. A model-based approach by structure was implemented frequently for studying population structure analysis in rice germplasm lines by various researchers Courtois et al. (2012); Surapaneni et al. (2016) and Li et al. (2020). Neighbour joining tree and principal coordinate analysis were strongly supported the results of population structure analysis and grouped the germplasm lines into two clusters based on the grain shape. The result of the current study was supported by Zhang et al. (2011); Upadhyay et al. (2012) and Li et al. (2020), as they were found two distinct subgroups (i.e. SG 1 and SG 2) within the entire rice germplasm. The overall results indicated that the whole population was divided into two different subgroups.

Understanding the basis of complex quantitative traits of economic importance is a major tactic behind the whole progress in plant breeding. Phenotypic variation in the form of changes in DNA sequence and their location in the genome have been traditionally performed using linkage mapping but during the past decade association mapping has shown great promise and power of mapping complex quantitative traits in plants as compared to traditional linkage mapping. Total 25 significant marker-trait associations were detected 
for four different traits. The results indicated that genome-wide association mapping may help to better understand the architecture of these traits and to discover novel trait-related genes. Agrama et al. (2007) identified 25 marker-trait associations of which, seven were identified as explaining $20 \%$ or more of the total variation (R2) for grain yield (RM261, RM228), kernel length (RM284), kernel length-width ratio (RM7, RM228), and total kernel weight (RM440, RM122). Association mapping in rice germplasm lines was successfully applied by Huang et al. (2011); Zhang et al. (2011); Li et al. (2011); Upadhyay et al. (2012); Surapaneni et al. (2016) and Li et al. (2020). Marker-trait associations detected through this study could be further validated and used in marker-assisted breeding for improving particular trait in any rice variety.

In this study, ample amount of variability was present which support their suitability for population structure and association mapping analysis. Rice germplasm were subdivided into two subgroups according to their grain shape which were further confirmed by neighbour joining tree and PCoA analysis. Germplasm lines which are distantly related or belongs different subgroups can be further used in the breeding program for developing hybrids. Total 25 significant marker-trait associations were detected for four different traits in which total 5 markers were significantly associated with grain length, 4 markers were associated with grain L:B ratio, 12 markers were associated with grain yield per plant and 4 markers were significantly associated with thousand grain weight, which can be further confirmed in new set of population as well as in bi-parental mapping population.

\section{Acknowledgements}

Authors are thankful to Professor \& Head, Department of Genetics and Plant Breeding, IGKV, Raipur, Professor \& Head, Department of Plant Molecular Biology and Biotechnology, IGKV, Raipur and In-charge Rice Biodiversity Division, IGKV Raipur.

\section{Conflict of interest}

The authors declare that they have no conflict of interest.

\section{References}

Agrama HA, Eizenga GC, Yan W (2007) Association mapping of yield and its components in rice cultivars. Molecular Breeding $19: 341-356$

Bai XF, Luo LJ, Yan WH, Kovi MR, Zhan W, Xing YZ (2010) Genetic dissection of rice grain shape using a recombinant inbred line population derived from two very contrasting parents and fine mapping a pleiotropic quantitative trait locus qGL7. BMC Genetics 11-16.

Bradbury PJ, Zhang Z, Kroon DE, Casstevens TM, Ramdoss Y, Buckler ES (2007) TASSEL, software for association mapping of complex traits in diverse samples. Bioinformatics 23: 2633-2635.
Courtois B, Frouin J, Greco R, Bruschi G, Droc G, Hamelin C, Ruiz M, Clément G, Evrard JC, Coppenole S (2012) Genetic diversity and population structure in a European collection of rice. Crop Science 52:1663-1675.

Devi KR, Parimala K, Venkanna V, Lingaiah N, Hari Y, Satish Chandra B (2016) Estimation of variability for grain yield and quality traits in rice (Oryza sativa $\mathrm{L}$.). International Journal of Pure and Applied Biosciences 4(2): 250-255.

Earl DA, vonHoldt BM (2012) STRUCTURE HARVESTER: a website and program for visualizing STRUCTURE output and implementing the Evanno method. Conservation Genetic Resources 4: 359-361.

Evanno G, Regnaut S, Goudet J (2005) Detecting the number of clusters of individuals using the software Structure: a simulation study. Molecular Ecology 14:2611-2620.

Huang R, Jiang L, Zheng J, Wang T, Wang H, Huang Y, Hong Z (2013) Genetic bases of rice grain shape: so many genes, so little known. Trends in Plant Science 18: 218-226.

Huang X, Zhao Y, Wei X, Li C, Wang A, Zhao Q, Li W, Guo Y, Deng L, Zhu C, Fan D, Lu Y, Weng Q, Liu K, Zhou T, Jing Y, Si L, Dong G, Huang T, Lu T, Feng Q, Qian Q, Li J, Han B (2011) Genome-wide association study of flowering time and grain yield traits in a worldwide collection of rice germplasm. Nature Genetics 44:32-39.

Li J, Xiao J, Grandillo S, Jiang L, Wan Y, Deng Q, Yuan L, McCouch SR (2004) QTL detection for rice grain quality traits using an interspecific backcross population derived from cultivated Asian (O. sativa L.) and African (O. glaberrima S.) rice. Genome 47:697-704.

Li P, Zhou H, Yang H, Xia D, Liu R, Sun P, Wang Q, Gao G, Zhang Q, Wang G, He Y (2020) Genome-Wide Association Studies Reveal the Genetic Basis of Fertility Restoration of CMSWA and CMS-HL in xian/indica and aus Accessions of Rice (Oryza sativa L.). Rice 13 (11): 1-12.

Li XB, Yan WG, Agrama H, Jia LM, Shen XH (2011) Mapping QTLs for improving grain yield using the USDA rice mini-core collection. Planta 234: 347-361.

Liu K, Muse SV (2005) Power Marker: an integrated analysis environment for genetic marker analysis. Bioinformatics 21: $2128-2129$

Mao H, Sun S, Yao J, Wang C, Yu S, Xu C, Li X, Zhang Q (2010) Linking differential domain functions of the GS3 protein to natural variation of grain size in rice. Proceedings of the National Academy of Sciences USA 107: 19579-19584. 
McKenzie KS, Rutger JN (1983) Genetic analysis of amylase content, alkali spreading score and grain dimensions in rice. Crop Science 23: 306-13.

Murray MG, Thompson WF (1980) Rapid isolation of high molecular weight plant DNA. Nucleic Acids Research 8:4321-4325.

Sahu PK, Mondal S, Sharma D, Sao R, Kumar V, Das BK (2019) Genetic insights into Fatty Acid components of traditional rice (Oryza sativa L.) landraces of Chhattisgarh, India. Indian Journal of Genetics and Plant Breeding 79(4) 651-657.

Sahu PK, Mondal S, Sharma D, Vishwakarma G, Kumar V, Das BK (2017) InDel marker based genetic differentiation and genetic diversity in traditional rice (Oryza sativa L.) landraces of Chhattisgarh, India. PLoS ONE 12(11): e0188864

Shao GN, Wei XJ, Chen ML, Tang SQ, Luo J, Jiao GA, Xie LH, $\mathrm{Hu}$ PS (2012) Allelic variation for a candidate gene for GS7, responsible for grain shape in rice. Theoretical and Applied Genetics 125:1303-1312.

Shomura A, Izawa T, Ebana K, Ebitani T, Kanegae H, Konishi S, Yano M (2008) Deletion in a gene associated with grain size increased yields during rice domestication. Nature Genetics 40: 1023-1028.

Surapaneni M, Divya B, Sukumar M, Raju AK, Rao VY, Neelamraju S (2016) Genetic characterization and population structure of Indian rice cultivars and wild genotypes using a core set markers. 3 Biotech 6:95.
Upadhyay P, Neeraja CN, Kole C, Singh VK (2012) Population structure and genetic diversity in popular rice varieties of India as evidenced from SSR analysis. Biochemical Genetics 50: (910):77-83.

Vanisree S, Anjali K, Damodar RC, Surender RC, Sreedhar M (2013) Variability, heritability and association analysis in scented rice. Journal of Bioscience Opinion 1(4): 347-352.

Wang S, Wu K, Yuan Q, Liu X, Liu Z, Lin X, Zeng R, Zhu H, Dong G, Qian Q (2012) Control of grain size, shape and quality by OsSPL16 in rice. Nature Genetics 44: 950-954.

Weng J, Gu S, Wan X, Gao H, Guo T, Su N, Lei C, Zhang X, Cheng Z, Guo X (2008) Isolation and initial characterization of GW5, a major QTL associated with rice grain width and weight. Cell Research 18: 1199-1209.

Xie XB, Jin FX, Song MH, Suh JP, Hwang HG, Kim YG (2008) Fine mapping of a yield-enhancing QTL cluster associated with transgressive variation in an Oryza sativa $\times$ O. rufipogon cross. Theoretical and Applied Genetics 116: 613-622.

Zhang P, Li JQ, Li XL, Liu XD, Zhao XJ (2011) Population structure and genetic diversity in a rice core collection (Oryza sativa L.) investigated with SSR markers. PLoS One 6: 12.

Zhang X, Wang J, Huang J, Lan H, Wang C, Yin C, Wu Y, Tang H, Qian Q, Li J (2012) Rare allele of OsPPKL1 associated with grain length causes extra-large grain and a significant yield increase in rice. PNAS USA 109: 21534-21539. 